\title{
Redesign of Core Courses for Product Design Majors: Practice-oriented and Application-oriented
}

\author{
WANG Li \\ Dalian University of Science and Technology, China
}

\begin{abstract}
This article briefly explains the training objectives of product design professionals and the restructuring plan of the core curriculum group. It focuses on the construction of an interdisciplinary core curriculum system, the introduction of a phased teaching organization model, the innovative use of maker project teaching methods, and the use of information technology to assist teaching. At this level, the specific ideas of redesigning the core courses of product design majors based on practice and application orientation were discussed, with a view to providing a reference for the teaching reform of industrial design and product design majors.
\end{abstract}

\section{Introduction}

Industrial development and transformation and upgrading have put forward urgent needs for the implementation of teaching reform in design disciplines. Product design majors must firmly adhere to the practice and applicationoriented, application-oriented innovative talents as the training target, and surround the curriculum system and teaching organization. The redesign of core professional courses is implemented at different levels to ensure the realization of professional differentiation and distinctive development, and to cultivate composite design talents that meet the needs of social development.

\section{Training goals of product design professionals and reconstruction of core curriculum groups}

\subsection{Design training objectives based on professional positioning}

The construction of core courses for product design majors should serve its talent training goals, and be committed to cultivating applied innovative talents that meet the requirements of social development and industrial transformation, and have strong theoretical foundations, innovative practical skills and comprehensive qualities. Deconstructing talent training goals in combination with product design specialty positioning, divides the students' capabilities into the following five levels: one is design thinking and innovation capabilities, and adhering to the user-centered concept to train students in vision, hands-on, communication, change Thinking ability, and achieve effective innovation in the aspects of lifestyle and product modeling; the second is the ability to predict and analyze the user's needs to achieve an accurate prediction of his future choice of lifestyle; The third is form appreciation and product modeling ability to optimize the aesthetic function of the final design product; the fourth is the ability to apply two-dimensional drawing and three-dimensional modeling software to ensure that students can flexibly use computer-aided modeling; the fifth is the ability to implement product functions and structural design, focusing on improving students' engineering realization capabilities [1]. For example, under the guidance of a teacher, use computer-aided design software to complete the engineering drawing of its design and design the threedimensional size of the product. The length of this product is $1500 \mathrm{~mm}$, the width is $1500 \mathrm{~mm}$, and the height is 1000 $\mathrm{mm}$. Digitization of assembly design provides important reference data. 


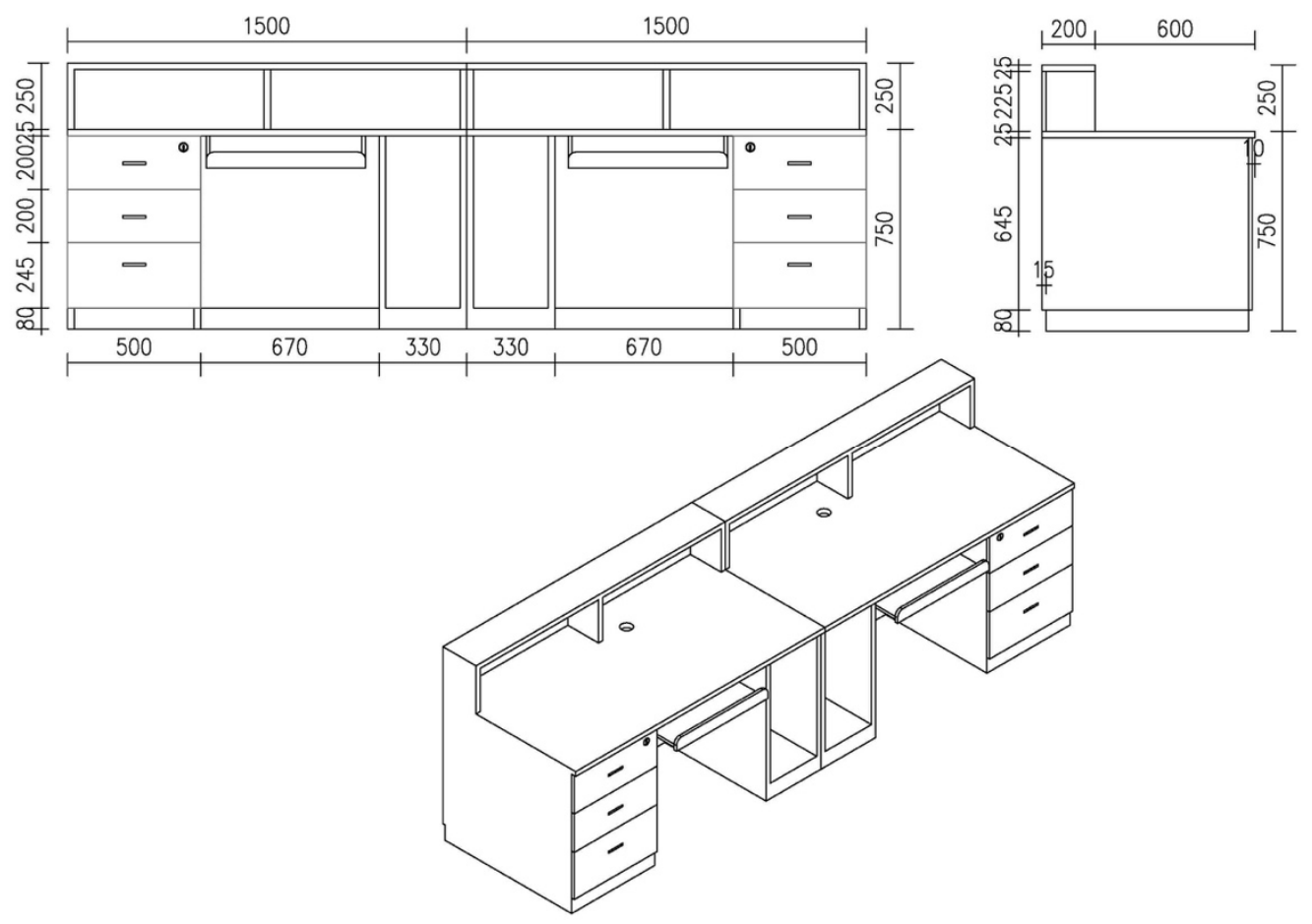

Figure 1. Engineering drawing example

\subsection{Reconstruction of the core curriculum group}

As product design is an interdisciplinary subject involving technology, humanities, art, society and other fields, it is necessary to realize the goal of core course redesign based on the construction of core course group, and coordinate the relationship between the overall structure of core course group and the construction of different internal course systems. Taking a university as an example, its core curriculum group is divided into the following four parts: The first is the product modeling design curriculum group, which consists of core courses such as shape design foundation, product shape design foundation, and product shape design. Creative design ideas and product modeling capabilities; the second is the product human factors design curriculum group, which consists of core courses such as ergonomics, user experience and product design, and is used to cultivate students' creative ability to lifestyle; the third is product structure Design course group, including materials and processing technology, industrial design machinery foundation, electrical engineering introduction, electromechanical equipment introduction and other courses, in an effort to train students to integrate manufacturing technology, material characteristics and other engineering design methods into product design; the fourth is product design and Develop a curriculum group that includes courses in design performance, model making, computer-aided modeling design, and computeraided structural design, and is committed to cultivating students' creative thinking and product design implementation capabilities.

\section{Discussion on the specific ideas for redesigning core courses of product design majors based on practice and application orientation}

\subsection{Establish a cross-disciplinary core curriculum system and define a coordinated development layout}

Generally, the construction effect of core courses will directly affect professional development. It is necessary to ensure that the redesign of core courses of product design major can effectively highlight the characteristics of core courses and be close to the direction of talent training.

First of all, colleges and universities should pay close attention to the development trends of the frontiers of product design, actively explore new design themes and design tools, and achieve teaching innovation on the basis of meeting students' knowledge and skills learning requirements. For example, the method for user experience maps can explore its Application in a variety of special situations to achieve innovation in teaching content, methods and tools. Secondly, we should deepen cross-professional and cross-domain exchanges and cooperation, build a school-level industrial design center and open it to multiple colleges, so as to build crossdisciplinary courses, add extra-curricular practice platforms, expand the perspective of discipline development, and cultivate students' comprehensive ability. Thirdly, we should focus on the areas of technology, materials, engineering and other fields for the development of characteristic practical teaching platforms, 
and rely on the construction of the laboratory to achieve the extension of the existing teaching platform. Next, it is necessary to promote the construction of a comprehensive teaching team, and match the corresponding teachers with multiple courses such as design basic courses, performance skills, design thinking and methods to provide intellectual support for the design and development of core courses with professional characteristics. Finally, we should focus on the level of practical innovation, promote cross-cooperation between product design and cultural industries, commerce, and creative industries, fully introduce intelligent technology and interactive means, and provide technical support for product design content, form, and method innovation.

\subsection{Introduce the teaching organization mode in stages, and deepen the integration of theory and practice}

Optimize the design of teaching organization mode based on practice and application orientation, mainly around the following three levels: The first is the introduction of a staged teaching model. Taking the product material technology course as an example, the gradient design of the teaching content implementation stage is based on the principle of easy to difficult. In the initial stage, it focuses on the research of gypsum, mud, wood and other materials to guide students. In the process of manufacturing models, gradually understand the material characteristics and master the processing technology; with the extension of the semester, students can gradually lead the study of the main materials and processing methods of marketcirculated products, guide students to complete product designs and try to make models on their own, and according to the design plan The feasibility is demonstrated. The second is to increase the proportion of practical teaching. Based on the students' grasp of the characteristics of common materials and processing technology, product cases are introduced to guide students in the collection, disassembly and assembly of products. In the process, students are guided to independently explore the material's shape, texture, and durability.

The last is to use the school-enterprise cooperation mechanism to promote the construction of enterprise inspection bases, and invite enterprise experts to hold lectures at the school, impart front-line work experience to students, and stimulate students' exploration interest; they can also guide students to visit the field for internships in the enterprise, such as explaining When knowledge of ceramic molding technology, students can be organized to go to the pottery art room to experience the pottery making process in order to enrich the students 'practical experience, deepen their perceptual knowledge, better improve the effectiveness of teaching, and cultivate students' practical skills [2].

\subsection{Innovative use of maker project teaching method to optimize teaching link design}

Given that product design majors have higher requirements for students' practical application skills, teachers need to fully learn from the maker education model, combine professional core curriculum teaching content with real maker projects and job capacity requirements, and rely on projects to drive student autonomy Learning and solving practical problems not only help mobilize students 'enthusiasm and enthusiasm for learning, but also help improve students' ability to analyze and solve problems. In the design of teaching links, we mainly start from the following levels:

The first is the project formulation and investigation and analysis. Taking leather goods design in fashion product design as an example, teachers can arrange students to complete the creation of handmade leather goods brands, leather goods product design and online sales promotion, focusing on brand image design, product scheme creativity and Performance, design, manual production and verification of dimension design project assessment indicators, and in the early stage of the project lead students to analyze fashion product trends and user positioning, guide students to complete market research and target user analysis independently, and lay a good foundation for subsequent design work. The second is business model planning and work plan formulation. At this stage, students are mainly guided to use visual charts to display brand operation content, conceive brand design and operation methods, complete the modular decomposition of brand project design, and determine the different project modules to be inspected. Specific content, for example, the leather goods design and production module is used to examine whether students can complete the cutting, punching, sewing, and sanding of long leather wallets according to the design paper, so that students create unique leather goods products. The third is project design realization, achievement display and market transformation. At this stage, students are arranged to complete project design tasks in group cooperation. Teachers need to focus on developing student maker skills such as leather sewing, jewelry welding, and polishing, as well as optional courses. The development guides students to learn cutting-edge technology, draw on typical product cases, and uses exhibition activities such as the Cultural Fair to build a platform for students to display results, and guides students to use the e-commerce platform for online promotion and offline marketing to achieve marketization and creation of design results Real value gain.

\subsection{Relying on information technology to assist teaching to cultivate students' application ability} In the context of "Internet + Education" implementation, teachers should also introduce information technology to assist core curriculum design, use sketching software, 3D software to aid design, etc. to exercise students' practical operation ability and speed up the process of professional integration. For example, teachers can arrange students to form a learning team of 4-5 people freely, and guide each learning team to simulate the industrial design process based on the theoretical knowledge they have learned and use existing practice places and resources, focusing on clarifying design content, conducting design surveys and information collection., Develop design and design sketches, draw outline design drawings and produce threedimensional grass molds, CMF design, optimization schemes, engineering design and model production, prototype testing and evaluation, modification and perfection, preparation of report design and display layout, 
etc., using computer software operations to complete Product design process and specific design tasks, make better use of the effectiveness of computer-assisted instruction, and achieve the cultivation of students' comprehensive application ability [3].

\section{Conclusion}

All in all, the construction of professional core courses at this stage has become an important measure for colleges and universities to deepen teaching reform and improve teaching quality, and puts forward higher requirements for the cultivation of students' professional core competence and comprehensive quality. Colleges and universities should closely combine the characteristics of professional education and talent training goals to promote the redesign of core courses in product design, ensure the effective improvement of students 'practical and application ability, and lay a good foundation for students' future career development.

\section{References:}

1. Ling Yan. Research on the reform of projectoriented industrial design research course [J]. Industrial Design, 2017, (2): 148-149.

2. Li Xiaofang. Research on the application model of flipping classroom based on micro-learning in the curriculum education of industrial design major [J]. New Campus (1st), 2018, (3): 65.

3. Wang Lili. Exploration of Project-based Practice Teaching Mode for Graduation Design_-Taking Product Design Major of Industrial Design Department of Hubei Institute of Technology as an Example [J] .Art Education, 2017, (5): 210-211.

4. Nie Shouhong. The construction of practical teaching mode of industrial design under various paradigms [J]. Education and occupation, 2015 (32): 108-110.

5. Yu Sui Huai, Hu Yukun, Chu Jianjie, et al. Research on the innovation mode of cross industrial design industry university research cooperation [J]. Packaging engineering, 2017 (12): 6-9. 